\title{
Dynamic Development of Dairy Cow Raising in Vietnam: A Review
}

\author{
Hoang Vu Quang* \\ Institute of Policy and Strategy for Agriculture and Rural Development, Vietnam
}

Submission: April 26, 2019; Published: May 29, 2019

*Corresponding author: Hoang Vu Quang, Institute of Policy and Strategy for Agriculture and Rural Development, 16 Tay Ho, Ha Noi, Vietnam

\begin{abstract}
This paper reviews the development of dairy cow raising in Vietnam in the last two decades. In the period 2001-2017, fresh milk production growths annually $14.7 \%$. The households have the tendency to raise more 10 cows. Processing companies invested much in dairy cow raising with total number of cows in company farms represent about one third. Processors buy milk directly from households or through their cooperative. The contribution of rapid growth of dairy cow raising in Vietnam are increased need of fresh milk, improved income of household, increased urban population and total population, very higher profit of dairy cow raising, improved technique and high technology, support of public services and policy.
\end{abstract}

Keywords: Dairy cow raising; Fresh milk; Supply chain; Processing company; Vietnam

Abbrevations: HH: Household; GDP: Gross Domestic Product; GNI: Gross National Income; VHLSS: Vietnam Household Living Standard Survey; GSO: General Statistical Office; VND: Vietnam Dong; Mil.: Million

\section{Introduction}

The dairy cow raising has been introduced to Vietnam from 1920s. Before 2001, the dairy cow raising in Vietnam was at a very small scale and low development level. The dairy cow raising began growing vigorously from 2001 thanks to promoting policy of Vietnamese Government. The fast increase of the income of Vietnamese people and the positive awareness of consumers create favorable condition for milk industry of Vietnam to fast develop in the last two decades. Thanks to that, the dairy cow raising also grows rapidly, resulting in positive transformations in direction of the enlargement of cow production scale and enhance the performance of the sector. This paper reviews the development of dairy cow raising sector of Vietnam, in particular in the last 10 years. Concretely, the paper presents the development of cow herd, milk production, productivity, model of production, dairy cow raising at small household, the coordination in value chains and factors affecting this development. The review is based on existing documents and analysis from secondary data.

\section{Number of Dairy Cow and Milk Production}

Source: GSO, 2019 [13].

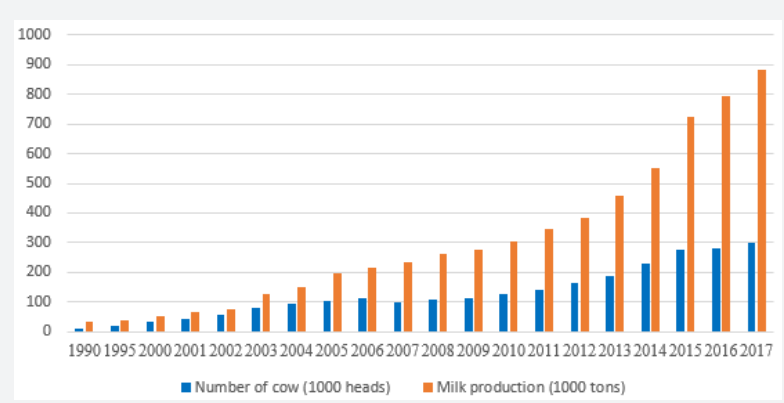

Figure 1: Evolution of dairy cow and milk production of Vietnam. 
Dairy cows raising in Vietnam registered in rapid growth since 1990s. The number of dairy cows and milk production has been incessantly increasing. In 1990, total dairy cows of Vietnam were only about 11 thousand of head, and then in 2017 is 301.6 thousand of cows. In the period 1990-2000, the cow increased every year about 2327 heads (annual growth rate is $11.6 \%$ ), the equivalent numbers in period 20010-2012 are 9114 cow (9.8\%), and for period 2013-2017 are 28580 cows (11.8\%). The fastincreasing number of cows in the period 2013-2017 come from the increase of cows raised by big companies as TH True Milk and Vina milk. In 2017, the fresh milk production of Vietnam achieved 881.3 thousand of tons, compared to 36.0 thousands of tons in 1990 and 55.1 thousand of tons in 2000 respectively. In the period 2001-2017, annual growth rate of domestic fresh milk production is $14.7 \%$. The increase of domestic milk production has made the contribution of increased number of cows and increased milk productivity. The increase of milk yield happens both in household farming and in big farms of companies. The data from Ho Chi Minh city, a big area of dairy cow raising, indicated the increase of milk productivity of a cow increased from 3.1 tons per milking cycle to 5.5 tons in 2013. However, milk productivity of companies is much higher because they use pure exotic breed while household mainly use cross breed of F1, F2, even F3 (Figure 1).

\section{Distribution of Dairy Cow Herd}

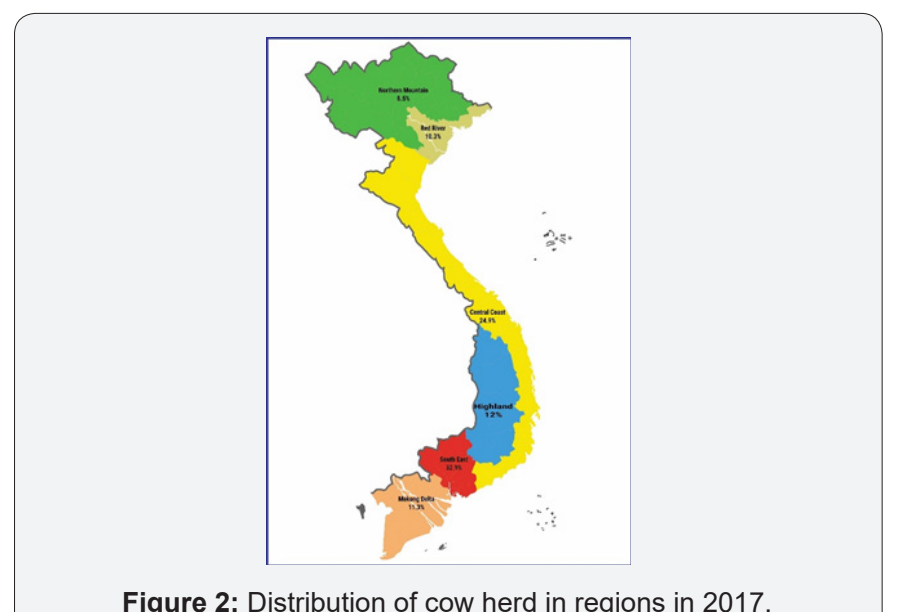

Figure 2: Distribution of cow herd in regions in 2017.

In 2001, dairy cow raising registered only in 12 provinces, in 2005 , dairy cow raising was expanded in 33 provinces and stable until now. However, cow herd is concentrated in some provinces. From 2010 to 2017, 10 provinces always represent more $90 \%$ of total cow herd of the whole country. In 2017, 2 provinces have biggest cow herd are Ho Chi Minh (28.0\%) and Nghe an (21.4\%). Some provinces have the sharp increase of cow herd thanks to investment of big companies in dairy cow raising. For example, the number of cows increased spectacularly in Nghe an province in last years because of number of cows raised by 2 big companies as TH True Milk and Vina milk. Only TH True Milk reported its cow herd of 45000 and Vina milk has just invested a mega farm of cow. Generally, the provinces having high number of dairy cows have climate condition favorable to dairy cow raising. The distribution of cow herd by region and by province is presented in Figures 2 $\& 3$.

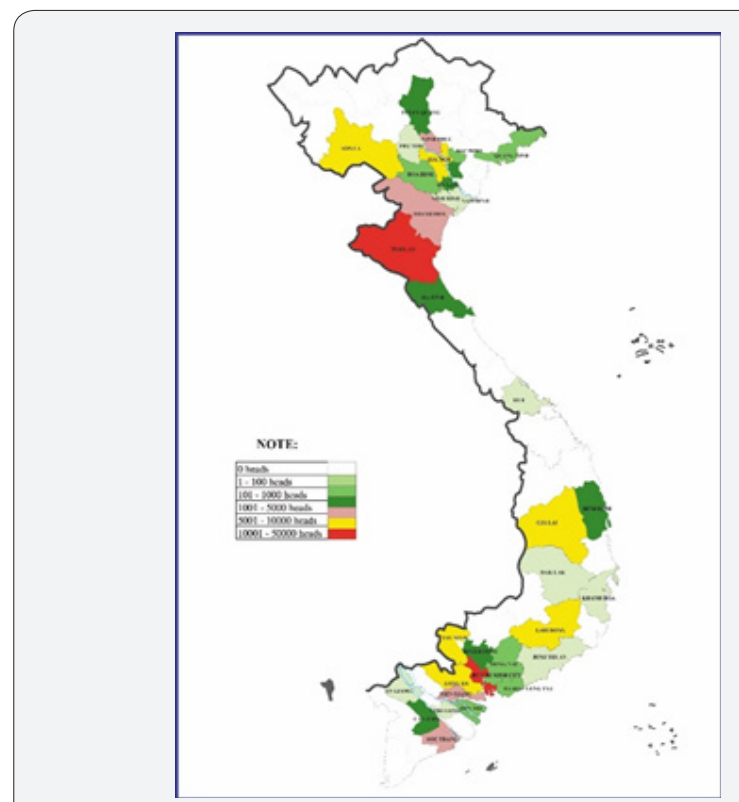

Figure 3: Distribution of Cow herd by province in 2017.

\section{Models of Dairy Cow Raising}

Dairy cow raising in Vietnam started in 1920s by the introduction of foreigners. In this period, dairy cows only were raised in farms of foreigners in 2 cities as Ha Noi and Sai Gon. The number of cows were about 300 heads and the milk productivity were very low (2-3 kg/head/day) [1]. In the South of Vietnam, before 1975, dairy cows were mainly raised in the suburb of Saigon city and at household level with scale of 10-20 heads/household, to provide fresh milk for the restaurants and consumers. Contrariwise, in Northern area from 1960 the Government developed State farms to raising dairy cows. These State farms were developed in the provinces with favorable natural condition (weather, land) as Ha Noi, Son La, Quang Ninh, Lai Chau, Lao Cai, Thanh Hoa. Dairy cow scale of State farms is less than 1000 heads, with breed of Holstein Friesian (HF). After the reunification in 1975, State farm for dairy cow raising is established in Lam Dong province in 1976 [1]. In summary, in the period of before 1986 when Vietnam had implemented centralized and planning economic system, dairy cow raising in Vietnam were mainly in the form of State farms. The dairy cow raising at household scale was not developed. The "innovation process" has been implementing in 1986 allows the development of household economics. Then, the dairy cow raising at household scale has been developed in the suburb of Ha Noi and Ho Chi Minh cities. The model of dairy cow raising household appeared firstly at the suburbs surrounding the big cities because of locating near the milk processing plants to save the transportation cost and avoid the quality damage caused by the inconvenient traffic and unsuitable preserved tools. In period 1986-1999, the dairy herds grew at average of $11 \%$ per year. 
Since the Government support policy was issued in 2001, the dairy cow raising of households has been strong developing, expanded in several provinces. In 2016, Vietnam has 32349 dairy cow raising households, representing $0.3 \%$ of agricultural forestry - fishery households. While dairy cow raising at household level develops rapidly, the State farms operate ineffectively. Consequently, the Government had the plan to restructure State farms in 2005. State farms were either privatized or redistributed their land to households for creating joint venture companies. Then, dairy cow raising consists of both individual households and milk processing companies. According to data of Department of Livestock Production [2], in 2018 the number of dairy cows owned by companies represent about one third of total herd of Vietnam. Some companies have numerous cows as TH True Milk (45000 cows), Vina milk (27000 cows), Moc Chau (25000 cows).

\section{Dairy Cow Raising at Households}

Nearly 70\% of cow herd is raised in small households. In 2016, there were 32349 cow raising households with an average of 6.4 cows per household [3]. The number of cows per households is very different among households and among regions. The current trend of dairy cow raising in Vietnam shows that the cow herd sized under 5 heads is now decreasing and the one sized over 5 heads is increasing. For example, in Ho Chi Minh city in 2005, households having less than 5 cows accounted for about $56 \%$ but this figure in 2013 is only $20 \%$. The number of households with cow herd sized from 10-49 has sharply increased (Table 1). The number of households with less 10 dairy cows reduced because unit production cost per milk kg of these households is higher than households with more than 10 cows (Table 1). Lower unit production cost of household with more 10 cows come from the exploitation of economic scale in using feed and labor [4]. In addition, in some cases, the trading companies wouldn't like to buy the milk from households with less than 10 cows. Remark: a Family labor for dairy cow raising is priced at cost for hired labor; $\mathrm{b}$ Turnover includes the revenue from selling milk, calf and waste; 1 USD = 23255 VND at exchange rate in April 2019 (Figure 4).

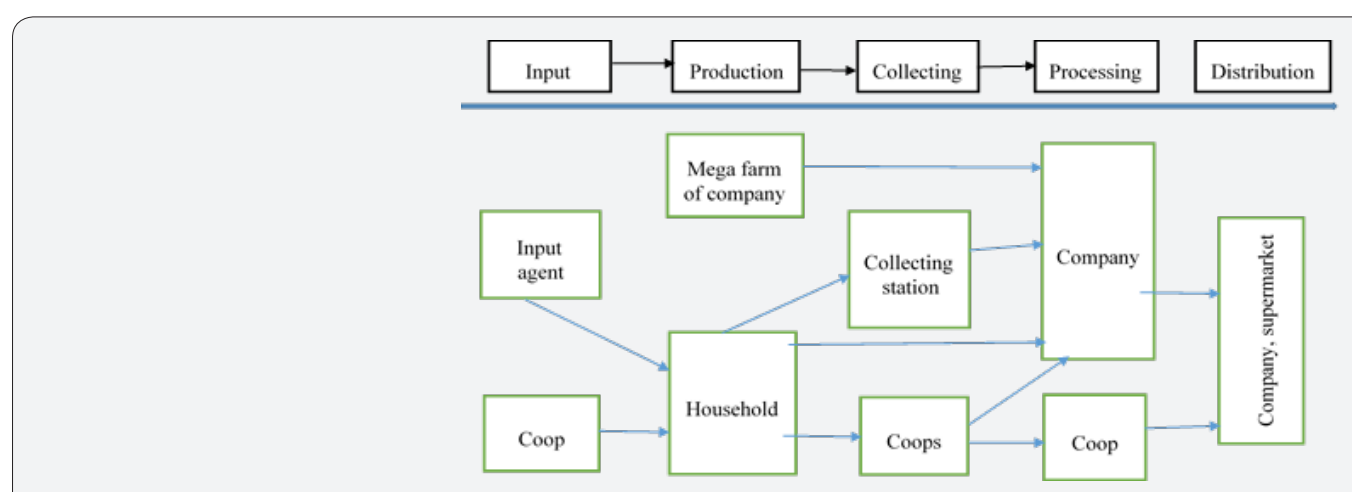

Source: Hoang Vu Quang, 2018 [5].

Figure 4: Mapping of stakeholders involved in milk supply chains in Vietnam.

Table 1: Proportion of dairy cow raising households by scale in Ho Chi Minh city.

\begin{tabular}{|c|c|c|c|c|c|c|}
\hline Year & $<5$ cows & 5 - 9 cows & $10-19$ cows & $20-49$ cows & $50-99$ cows & 100 cows and over \\
\hline 2005 & 56.8 & 30.1 & 11.0 & 1.8 & 0.1 & 0.1 \\
\hline 2006 & 49.7 & 33.7 & 14.0 & 2.4 & 0.2 & 0.1 \\
\hline 2007 & 43.6 & 34.3 & 17.5 & 4.1 & 0.4 & 0.1 \\
\hline 2008 & 35.6 & 38.0 & 20.2 & 5.5 & 0.5 & 0.2 \\
\hline 2009 & 25.6 & 45.1 & 22.3 & 6.4 & 0.4 & 0.1 \\
\hline 2010 & 25.0 & 44.3 & 23.1 & 7.0 & 0.5 & 0.2 \\
\hline 2011 & 28.3 & 36.4 & 25.7 & 9.0 & 0.5 & 0.1 \\
\hline 2012 & 25.0 & 34.2 & 28.5 & 11.3 & 1.0 & 0.1 \\
\hline 2013 & 21.2 & 34.0 & 30.3 & 13.1 & 1.2 & 0.1 \\
\hline
\end{tabular}

Source: Author's calcul from data of Ho Chi Minh [3].

Even increased, the milk productivity of households is much less than one of companies. That comes from the fact that about $90 \%$ of dairy cows raised in households are crossbreed, mainly
F2 and F3. Only about $10 \%$ of cows are pure exotic breed. About $50 \%$ of households use only calves reproduced by their cows and $50 \%$ remain households use both their calves and calved bought 
outside households [4]. Nearly $100 \%$ of households use industrial feed for cows, in which $50 \%$ only used industrial feed and $50 \%$ use both bought industrial feed and feed mixed by themselves (Table 2) (Figure 5).

Source: Hoang Vu Quang and Ta Van Tuong, 2016 [9].

Figure 5: Rate of farmers own machine and equipment for dairy cow caring.

Table 2: Economic performance of dairy cow raising by cow scale.

\begin{tabular}{|c|c|c|c|c|c|}
\hline Indicator & Unit & Total & < 5 cows & $\mathbf{5 - 9}$ cows & 10 cows and over \\
\hline Milk productivity/milking cycle & $\mathrm{kg}$ & 4666 & 4529 & 4610 & 4820 \\
\hline Production cost of 1 kg fresh milk & 1000 VND & 8.88 & 9.82 & 9.04 & 8.23 \\
\hline Turnover of 1 kg fresh milk & 1000 VND & 12.5 & 12.1 & 12.2 & 13.0 \\
\hline Profit of 1 kg fresh milk & 1000 VND & 3.6 & 2.3 & 3.2 & 14.8 \\
\hline Profit of 1 dairy cow in a year & Mil. VND & 16.8 & 10.4 & 23.1 \\
\hline $\begin{array}{c}\text { Income (profit + family labor cost) of household from cow } \\
\text { raising in 1 year }\end{array}$ & Mil. VND & 139.5 & 71.0 & 115.0 & 219.6 \\
\hline
\end{tabular}

Source: Synthesis from Hoang Vu Quang and Ta Van Tuong [10].

\section{Supply chain and Vertical Coordination}

Because of characteristics of fresh milk is quickly spoiled in normal condition, fresh milk need to be preserved in cool condition just after milking, so the vertical coordination in fresh milk supply chain is very high. Nearly $100 \%$ of households have presently the contract with milk processors.

Based on stakeholders involved in fresh milk supply chain, it can classify in 5 supply chains in Vietnam in present time as following:

a. Supply chain 1: Household - local and small processor local market. This supply chain represents a small proportion of producers and milk volume. For example, about $4 \%$ of fresh milk in Lam Dong province in 2017 were not signed the contract with processing companies. That come from new producers or households violated the engagement with buyers and are out of contract as punished measure. These producers sell their milk to small processors to produce milk cake or artisanal milk processing [5].

b. Supply chain 2: Household - processing companies domestic market. This is important chain in term of milk volume. For example, $84 \%$ of fresh milk produced in Lam Dong provinces are sold in this chain [5]. The processing companies sign contract farming directly with individual household. The cow producers normally have to meet the requirement of processors as cow scale, used feed, hygiene and disinfection measures, antibiotic use, etc. The processing companies can support households as giving training course, support for treating diseases [6]. The companies usually put collecting stations nearly households to receive their milk.

c. Supply chain 3: Household - cooperative - processing companies - domestic market. Some processing companies purchase fresh milk from cooperative. In this case, the cooperatives like fresh milk collecting stations for the companies. These cooperatives have the infrastructure and equipment for buying, preserving milk in cooled system. However, we registered in 2018 only some cooperatives in doing that such Eve growth cooperative in Soc Trang and Tan Thong Hoi cooperative in Ho Chi Minh [7]. The companies do not want to sign the contract with agricultural cooperative because of limited capacity of cooperatives.

d. Supply chain 4: Household - cooperative - domestic market. One new tendency emerging from 2017 is that the cooperatives involves directly in milk processing and commercialize milk products. These 2 cooperatives have experience in preserving fresh milk and good operation. They 
want to involve in processing milk in aiming to ensure the market for fresh milk and have more added values for their members. This event happens in Eve growth cooperative in Soc Trang and Tan Thong Hoi cooperative in Ho Chi Minh [7]. However, the processing scale is very limited when the cooperatives have to compete with well-known companies and to face difficulty in looking for the market for their products.

e. Supply chain 5 (closed chain): big fames of processing company - processing companies - domestic market. Some milk processing companies organize dairy cow raising to self-supply fresh milk to their processing factories. Normally, these are mega farms with high tech application and pure exotic breed. For example, TH True Milk have mega farm of 45000 imported exotic cows and raised in housing with Israeli technology. Vina milk organizes also mega farms of exotic breeds and organic farm.

In summary, milk processors are main actor in supply chains of fresh milk when they are main buyers and producers.

\section{Factors Impacting Dairy Cow Raising}

\section{Increased domestic demand of fresh milk}

The results from VHLSS 2008 -2016 indicated that the proportion of households the consume liquid milk and consumption volume of liquid milk have been incessantly increasing in this period. Concretely, in $2008,21.1 \%$ of households consuming liquid milk with the volume of $17.1 \mathrm{~kg} /$ year and in
2017 there are $36.4 \%$ households consuming $29.0 \mathrm{~kg} /$ year [6]. The increase in consumption of liquid milk is registered both in rural and urban areas (Table 3). The awareness of the consumers on positive effects of milk on the growth, development, human health and disease prevention is an important factor in fostering the milk consumption. The communication programs given by public media, private sector, etc. play a key role in the change of consumer's awareness. As an evidence, the study result of Hoang Vu Quang in 2019 [8] indicated that the consumption of liquid milk increases averagely every year, if all others remain unchanged, $2.33 \mathrm{~kg} / \mathrm{HH}$.

\section{Increased Income and Urban Population}

The study of Hoang Vu Quang in 2019 found positive effect of household's income and urban population on liquid milk consumption. Accordingly, the income elasticity is 0.079 and an urban household consumes higher $6.3 \mathrm{~kg} /$ year than rural household. The innovation of economic mechanism, the industrialization, urbanization and the depth integration into world economy allow Vietnam to have high growth rate of GDP in long period and improve the income of households (Table 4). In the period 2000-2017, the GNI per capita increase annually $4.7 \%$. The liquid milk consumption of urban area is higher than rural area in term of household proportion, volume and share of income (Table 3). So, rapid growth of urban population (Table 4) speeds up milk consumption in Vietnam. The continuous urbanization process fosters the volume of milk for food in Vietnam in the coming time.

Table 3: Consumption of liquid milk in urban and rural areas of Vietnam.

\begin{tabular}{|c|c|c|c|c|c|c|}
\hline Indicator & Area & 2008 & 2010 & 2012 & 2014 & 2016 \\
\hline \multirow{3}{*}{$\begin{array}{l}\text { Proportion of households consuming liquid } \\
\text { milk }\end{array}$} & Whole country & 21.1 & 22.6 & 26.5 & 21.5 & 36.4 \\
\hline & Urban & 36.9 & 34.5 & 37.8 & 24.3 & 46.5 \\
\hline & Rural & 15.6 & 17.9 & 21.9 & 20.3 & 32.1 \\
\hline \multirow{3}{*}{$\begin{array}{c}\text { Consumed volume of liquid milk }(\mathrm{kg} / \mathrm{HH} / \\
\text { year) }\end{array}$} & Whole country & 11.7 & 20.7 & 18.6 & 15.5 & 29.0 \\
\hline & Urban & 5.0 & 8.2 & 7.0 & 4.2 & 9.4 \\
\hline & Rural & 1.2 & 3.0 & 3.1 & 3.2 & 5.3 \\
\hline \multirow{3}{*}{$\begin{array}{l}\text { Proportion of HH's income spends for liquid } \\
\text { milk }\end{array}$} & Whole country & 0.9 & 1.5 & 1.6 & 1.4 & 2.0 \\
\hline & Urban & 1.4 & 2.1 & 2.0 & 1.4 & 2.1 \\
\hline & Rural & 0.7 & 1.2 & 1.4 & 1.4 & 1.9 \\
\hline
\end{tabular}

Source: Author's calcul from VHLSS 2008, 2010, 2012, 2014, 2016.

Table 4: Growth of GDP, GNI per capita and population of Vietnam.

\begin{tabular}{|c|c|c|c|c|}
\hline Year & Growth rate of GDP & GNI per capita (constant 2010 US\$) & Population (Mil. person) & Urban population (\%) \\
\hline 2000 & 6.8 & 806.1 & 77.6 & 24.1 \\
\hline 2001 & 6.2 & 848.2 & 78.6 & 24.5 \\
\hline 2002 & 6.3 & 892.7 & 79.5 & 25.0 \\
\hline 2003 & 6.9 & 942.9 & 80.5 & 25.8 \\
\hline 2004 & 7.5 & 1009.7 & 81.4 & 26.5 \\
\hline 2005 & 7.5 & 995.1 & 82.4 & 27.1 \\
\hline 2006 & 7.0 & 1051.3 & 83.3 & 27.7 \\
\hline
\end{tabular}


Journal of Dairy \& Veterinary Sciences

\begin{tabular}{|l|l|l|l|l|}
\hline 2007 & 7.1 & 1108.9 & 84.2 & 28.2 \\
\hline 2008 & 5.7 & 1158.2 & 85.1 & 29.0 \\
\hline 2009 & 5.4 & 1095.1 & 86.0 & 29.7 \\
\hline 2010 & 6.4 & 1260.4 & 86.9 & 30.5 \\
\hline 2011 & 6.2 & 1317.5 & 87.9 & 31.5 \\
\hline 2012 & 5.2 & 1373.3 & 88.8 & 31.8 \\
\hline 2013 & 5.4 & 1427.4 & 89.8 & 32.2 \\
\hline 2014 & 6.0 & 1488.0 & 90.7 & 33.1 \\
\hline 2015 & 6.7 & 1564.1 & 91.7 & 33.9 \\
\hline 2016 & 6.2 & 1659.1 & 92.7 & 34.4 \\
\hline 2017 & 6.8 & 1740.7 & 93.7 & 35.0 \\
\hline
\end{tabular}

Source: data on GDP, GNI per capita from World Bank [14]; data on population from GSO [13].

\section{High profit of cow raising}

The dairy cow raising brings higher income for the farmers than other agricultural production activities (as poultry, pork, rice). The study in 2012 of Le Thi Phi Van [9] indicated that annual income of a dairy cow is equivalent to income of raising 106 pork's. In Tien Giang province, profit rate is $37 \%$, in Ho Chi Minh city, the profit rate is from $1.9 \%$ to $27 \%$ in function of raising scale $1.9 \%$ for scale less than 5 cows and $27 \%$ for scale from 50 cows and over). Study of Hoang Vu Quang and Ta Van Tuong in 2018 [6] also indicated that a dairy cow raising brings to farmers in Northern provinces an income of 28.3 million VND and 1 ha of annual crop land can cultivate the grass and provide to 13 cows. Meanwhile, 1 ha of rice only brings to farmer from 10 to 20 million VND. So, in term of land use performance, 1 ha of land used for cultivating cow grass can bring an income of 15 time higher if this land is used for rice cultivation. In addition, in the last 20 years there was no crisis of milk price as happened with pork price [10-12]. The profitable rate of dairy cow raising is key factor for booming of dairy cow raising at household level in the last two decades.

\section{Role of milk processing companies}

The role of milk processing companies is manifested in 2 aspects: 1) because of domestic need to fresh milk increase rapidly, the milk processing companies have to reinforce milk purchase from farmers, support the cow farmers (providing milk cow, technique training and guidance, advance feed, etc.). This fosters the farmers to invest in dairy cow raising (increase the number of cow farmers, increase the number of cows per farmer); 2) the companies invest directly in the activity of dairy cow raising. Several provinces change suddenly the number of cows in some years due to the investment of processing companies in dairy cow raising in these provinces. With numerous cows and high milk productivity, the processing companies have big contribution into increase of milk production of Vietnam in last year's $[13,14]$.

\section{Technology}

Advanced technique, modern and high technology have made important contribution to the development of dairy cow raising in Vietnam. The use of industrial feed in combination with green feed allow the farmers to increase the number of dairy cow and improve milk productivity. Most dairy cow farmers use machine, equipment in caring cows, and doing hygiene, disinfection measures. That increase labor productivity and the number of cows raised by a labor. The artificial insemination is applied in all farms with exotic sperm. That helps to improve the quality of dairy cow. With companies, the tendency is to use exotic breed with high productivity, applied high technology, so milk productivity of companies is very high.

\section{Supporting policy}

The Government has several policies and measure to support the dairy cow producers and attract the companies to invest in dairy cow raising. For individual households, the government provide training course, including trainings on caring, feed use, veterinary measure, use of antibiotics, hygiene and disinfection, milking, etc. The households are supported for vaccination, use of diet test, artificial insemination, buying equipment for caring animals (grass cutting machine, feed slicer, spraying machine, etc.). For company, they are supported in the building of infrastructure for dairy cow raising as road, electricity system, water system, animal waste treatment system, factory and buying equipment. The companies are supported by 10 million VND/head for imported dairy cow with high milk productivity. The companies also are facilitated in renting land for dairy cow farms and are exempted or reduced the tax on land use right.

\section{Conclusion}

The dairy cow raising of Vietnam registers a rapid transformation in the last two decades. Dairy cow raising is expanded in more than a half of provinces with 32349 dairy cow raising households. The households with less than 10 cows tend to be reduced while households with more 10 cows increase. Several big processing companies invested in dairy cow rising help to increase rapidly milk production of Vietnam. The development of dairy cow raising in Vietnam has made contribution from several factors. The consumption needs of liquid milk thanks to increased income, the increase of population and urban people, increased awareness of consumers on positive effect of milk. 
Improved technology helps to increase milk productivity and labor production, facilitating the farmers to increase their cow herd. The most important element can be higher profit from dairy cow raising than several other agricultural activities. The development of dairy cow households has the support of public services in providing training courses, guidance in the application.

\section{References}

1. Cai Dinh Van (2009) Research and development of dairy cow raising in Vietnam.

2. Department of Livestock Production (2014) Report on current situation of dairy production in Vietnam.

3. General Statistical Office (2018) Results of the rural, agricultural and fishery census 2016. Statistic Publishing House.

4. Quang Hoang Vu, Tuong Ta Van (2016) Dairy cow raising of households in Vietnam. Study report in the Project Development of a livestock policy analysis and monitoring system in Vietnam.

5. Quang Hoang Vu, Huy Hoang Minh, Ba Nguyen Van (2018) Current situation and solutions for developing milk value chains in Lam Dong province [in origin: Thuc trang va giai phap phat trien chuoi gia tri sua tinh Lam Dong]. Study report for The Vietnam Cooperative Enterprise Development (VCED) Project.

6. Quang Hoang Vu, Khanh Pham Duy, Nguyen Bui Quang, Anh Bui Tuan Ba Nguyen Van (2017) policies to promote linkage in production and consumption of livestock products. Study report.
7. Quang Hoang Vu (2018) Role of cooperative in supporting small households in involving in milk value chain. Journal of Agriculture and Rural Development, No 8/2018, p. 20-27.

8. Quang Hoang Vu (2019) Factors affecting fresh milk consumption of Vietnamese households. Livestock Research for Rural Development. Volume 31: 3 .

9. Van Le Thi Phi (2012) Methods for development of Dairy cow raising in Vietnam [in origin: Phuong pháp phat trien chan nuoi bo sua o Viet Nam]. Study report.

10. Ba Nguyen Van, Quang Hoang Vu, Huy Hoang Minh (2018) Current situation and solutions for developing milk value chains in Soc Trang province. Study report for The Vietnam Cooperative Enterprise Development (VCED) Project.

11. Department of Agriculture and Rural Development of Ho Chi Minh City (2014) Report on result of development program of dairy cow raising in 2013 in Ho Chi Minh City.

12. Quang Hoang Vu, Tuong Ta Van (2018) Economic performance of dairy cow raising at household scale in Red River Delta. Journal of Economics and Forecast 15: 65-68.

13. General Statistical Office (2019) http://www.gso.gov.vn/Default aspx?tabid=706\&ItemID $=13412$

14. Work Bank (http://data.worldbank.org/country/vietnam)

\section{Your next submission with Juniper Publishers will reach you the below assets}

- Quality Editorial service

- Swift Peer Review

- Reprints availability

- E-prints Service

- Manuscript Podcast for convenient understanding

- Global attainment for your research

- Manuscript accessibility in different formats

( Pdf, E-pub, Full Text, Audio)

- Unceasing customer service

Track the below URL for one-step submission https://juniperpublishers.com/online-submission.php 